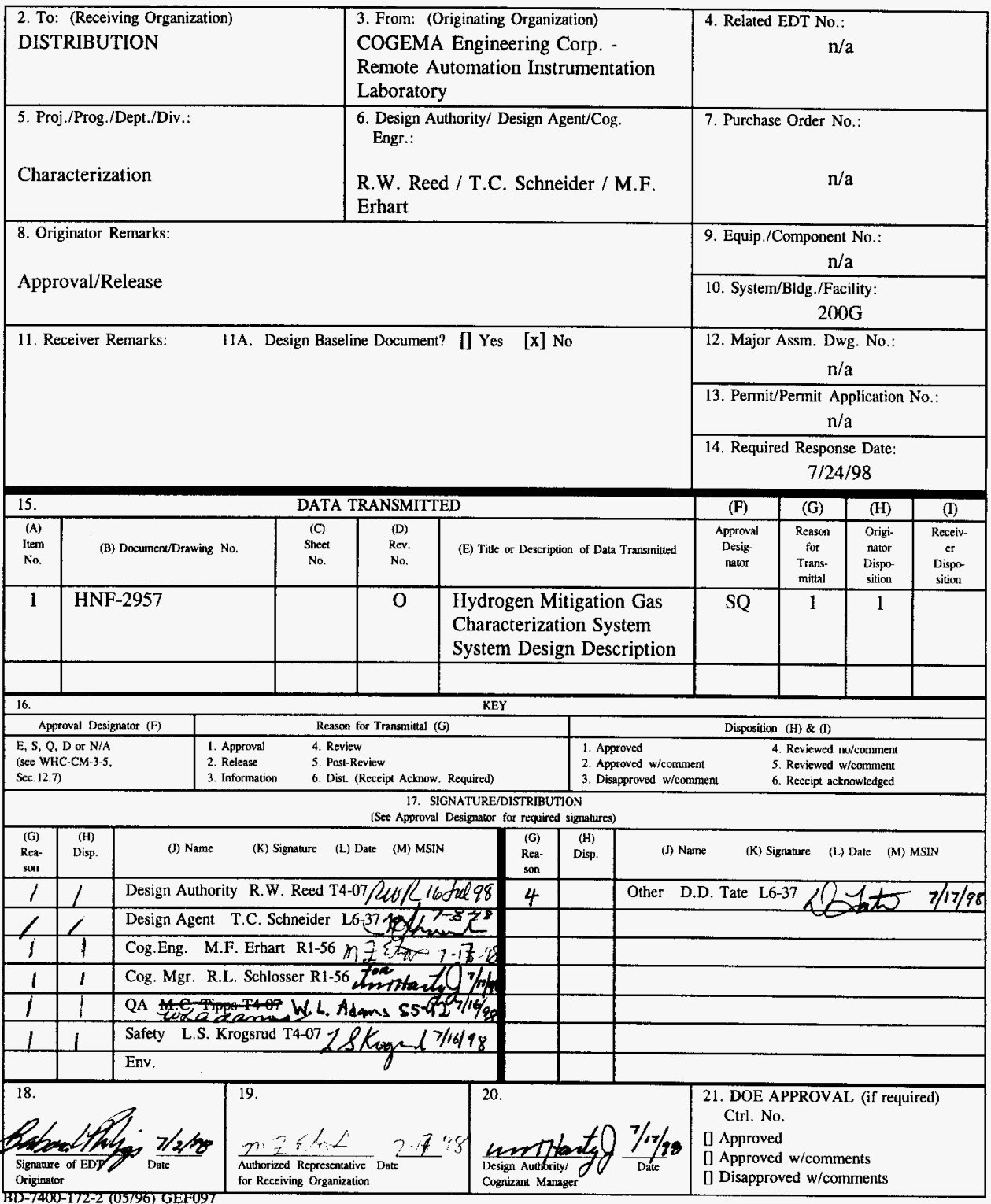


HNF-2957, Rev. 0

\section{HYDROGEN MITIGATION GAS \\ CHARACTERIZATION SYSTEM \\ SYSTEM DESIGN DESCRIPTION}

T. C. Schneider

Numatec Hanford Company, Richland. WA 99352

U.S. Department of Energy Contract DE-AC06-96RL 13200

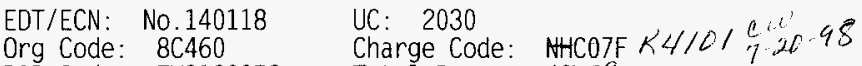

B\&R Code: EW3120072 Total Pages: 4039

Key Words: Standard Hydrogen Monitoring System (SHMS)

Abstract:

Gas Characterization System (GCS) system design description

for flammable gas monitoring.

TRADEMARK DISCLAIMER. Reference herein to any specific commercial product. process, or service by trade name, trademark, manufacturer, or otherwise. does not necessarily constitute or imply its endorsement, recommendation, or favoring by the United States Government or any agency thereof or its contractors or subcontractors.

Printed in the United States of America. To obtain copies of this document, contact: WHC/BCS Document Control Services, P.0. Box 1970. Mailstop H6-08. Richland WA 99352. Phone (509) 372-2420;

Fax (509) 376-4989.

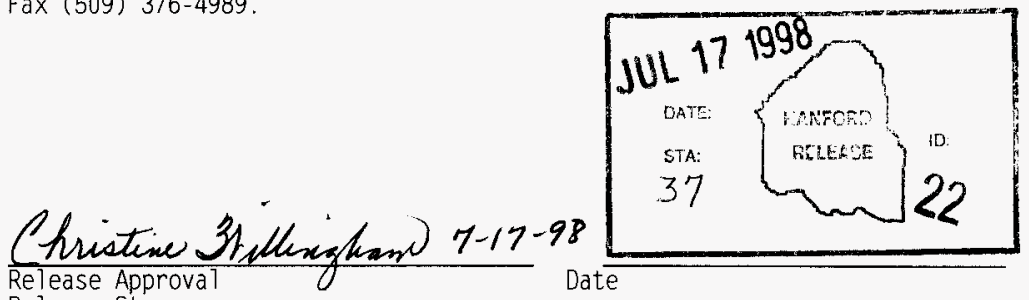

Release Stamp 


\section{HYDROGEN MITIGATION}

\section{GAS CHARACTERIZATION SYSTEM \\ SYSTEM DESIGN DESCRIPTION}

HNF-2957

\section{PREPARED BY}

T. C. Schneider \& B. L. Philipp

July 1998

TWRS Safety Special Projects 


\section{CONTENTS}

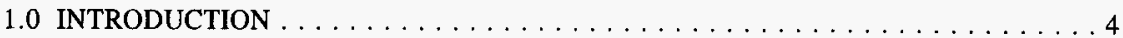

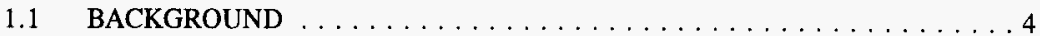

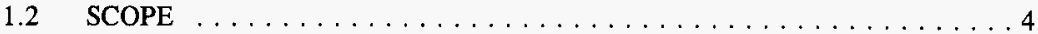

2.0 FUNCTIONS AND DESIGN REQUIREMENTS $\ldots \ldots \ldots \ldots \ldots \ldots \ldots$

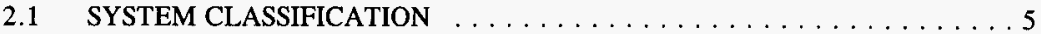

2.2 TEST FACILITY REQUIREMENTS $\ldots \ldots \ldots \ldots \ldots \ldots \ldots \ldots$

2.3 SAMPLE GAS DELIVERY SYSTEM REQUIREMENTS $\ldots \ldots \ldots \ldots \ldots 6$

2.4 SAMPLE GAS ANALYTICAL SYSTEM REQUIREMENTS $\ldots \ldots \ldots \ldots 7$

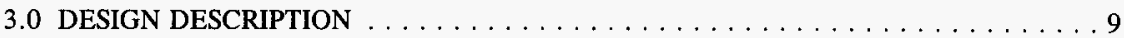

3.1 GAS SAMPLING PNEUMATIC SYSTEM $\ldots \ldots \ldots \ldots \ldots \ldots$

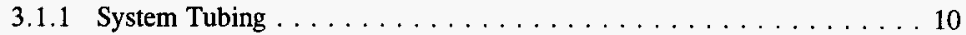

3.1 .2 System Isolation Valves $\ldots \ldots \ldots \ldots \ldots \ldots \ldots \ldots \ldots \ldots$

3.1.3 Sample Inlet Filter System . . . . . . . . . . . . . . 10

3.1 .4 Gas Chromatograph Sample Gas Loops . . . . . . . . . . . . . . 10

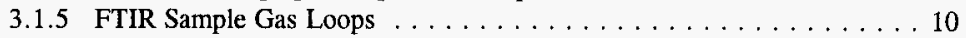

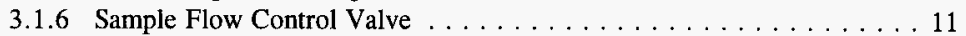

3.1 .7 Sampling Vacuum Pump $\ldots \ldots \ldots \ldots \ldots \ldots \ldots \ldots \ldots \ldots \ldots$

3.1.8 Sample Exhaust Backflow Preventer . . . . . . . . . . . . 11

3.2 GAS SAMPLING INSTRUMENTATION SYSTEMS $\ldots \ldots \ldots \ldots \ldots \ldots 11$

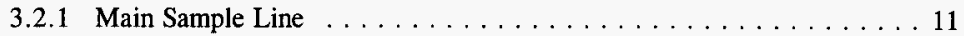

3.2.1.1 Inlet Filter Differential Pressure $\ldots \ldots \ldots \ldots \ldots \ldots \ldots 11$

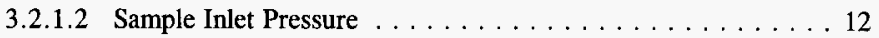

3.2.1.3 Sample Flow Indication . . . . . . . . . . . . 12

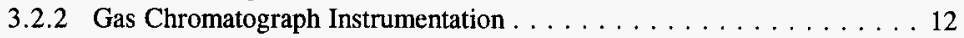

3.2.2.1 Chromatograph Columns and Detector . . . . . . . . 12

3.2.2.2 Differential Pressure . . . . . . . . . . . . . . 13

3.2.2.3 Sample Flow Control and Indication $\ldots \ldots \ldots \ldots \ldots 13$

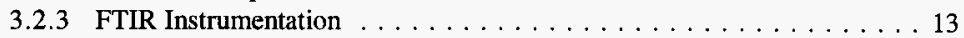

3.2.3.1 Light Source and Detection System . . . . . . . . . 13

3.2.3.2 Signal Processing System . . . . . . . . . . . . . . . 13

3.2.3.3 Cell Sample Gas Temperature . . . . . . . . . . . . . . . 14

3.2.3.4 Cell Sample Gas Absolute Pressure . . . . . . . . . . . 14

3.2.3.5 Sample Gas Flow Indication . . . . . . . . . . . . . . 14

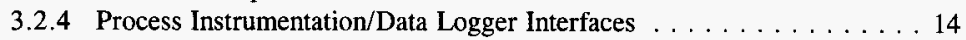

3.3 CALIBRATION, CARRIER, AND PURGE GAS SYSTEM . . . . . . . . . 14

3.3.1 Automatic Calibration Gas Supply . . . . . . . . . . . . . . 14

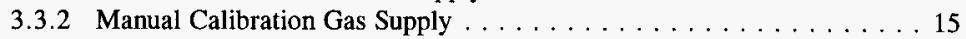

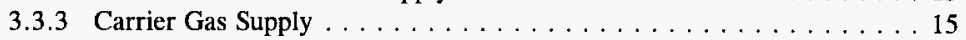

3.3 .4 FTIR Purge Gas Supply $\ldots \ldots \ldots \ldots \ldots \ldots \ldots \ldots \ldots \ldots$ 
3.4 GCS POWER DISTRIBUTION $\ldots \ldots \ldots \ldots \ldots \ldots \ldots \ldots \ldots \ldots$

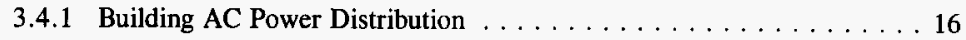

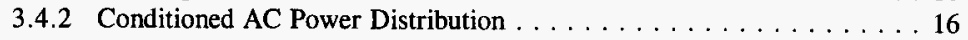

3.4.3 Instrumentation DC Power Distribution $\ldots \ldots \ldots \ldots \ldots \ldots$

3.5 HEAT TRACE AND ENVIRONMENTAL CONTROL $\ldots \ldots \ldots \ldots \ldots 17$

3.5.1 Sample Gas Line Heat Trace Control and Monitoring $\ldots \ldots \ldots \ldots 17$

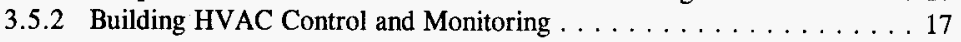

4.0 SYSTEM LIMITATIONS AND RESPONSE TO CASUALTY EVENTS . . . . . . . . . 18

4.1 BREACH OF SAMPLING SYSTEM CONTAINMENT $\ldots \ldots \ldots \ldots \ldots 18$

4.2 TOTAL LOSS OF FACILITY POWER $\ldots \ldots \ldots \ldots \ldots \ldots \ldots \ldots$

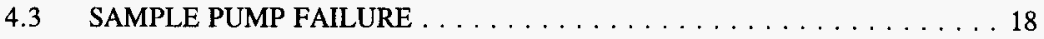

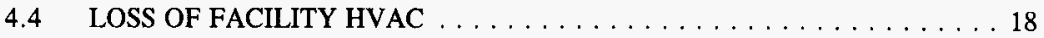

5.0 OPERATION . . . . . . . . . . . . . . . . . . . . . . . . . 19

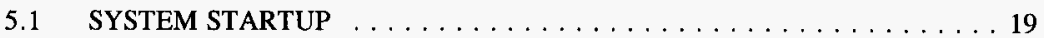

5.2 PERFORM A FUNCTIONAL VALIDATION ON EACH GAS

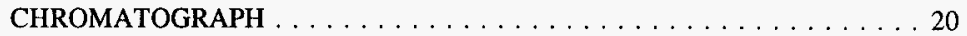

5.3 PERFORM A FUNCTIONAL VALIDATION ON THE FTIR . . . . . 20

5.4 PERFORM A ROUTINE SYSTEM LEAK CHECK $\ldots \ldots \ldots \ldots \ldots \ldots$

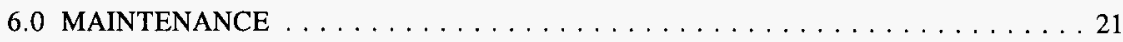

7.0 REFERENCES . . . . . . . . . . . . . . . . . . . . . . . 22

7.1 GENERAL GOVERNMENT AND REGULATORY DOCUMENTS . . . . . 22

7.2 HANFORD GENERATED ENGINEERING DOCUMENTS $\ldots \ldots \ldots \ldots 22$

APPENDIX A - GCS DRAWING/SUPPORTING DOCUMENT LIST . . . . . . . . 23

APPENDIX B - MAJOR COMPONENTS LIST $\ldots \ldots \ldots \ldots \ldots \ldots \ldots \ldots \ldots$

APPENDIX C - Gas Sample Delivery Speed Calculations . . . . . . . . . . . . . . . 29

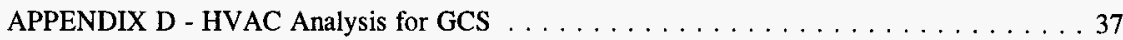

\section{LIST OF FIGURES}

Figure 1 - SYSTEM BLOCK DIAGRAM $\ldots \ldots \ldots \ldots \ldots \ldots \ldots$ 


\subsection{INTRODUCTION}

\subsection{BACKGROUND}

Tank 241-SY-101 (SY-101) is known to experience periodic tank level increases and decreases during which hydrogen gas is released. It is believed that the generated gases accumulate in the solids-containing layer near the bottom of the tank. Solids and gases are also present in the "crust" and may be present in the interstitial liquid layer. The accumulation of gases creates a buoyancy that eventually overcomes the density and bonding strength of the bottom layer. When this happens, the gas from the bottom layer is released upward through the liquid layer to the vapor space above the tank crust. Previous monitoring of the vapor space gases during such an event indicates hydrogen release concentrations greater than the lower flammability limit (LFL) of hydrogen in a partial nitrous oxide atmosphere.

Tanks 241-AN-105, 241-AW-101, and 241-SY-103 have been identified as having the potential to behave similar to SY-101. These waste tanks have been placed on the flammable gas watchlist (FGWL). All waste tanks on the FGWL will have a standard hydrogen monitoring system (SHMS) installed to measure hydrogen. In the event that hydrogen levels exceed $0.75 \%$ by volume, additional characterization will be required. The purpose of this additional vapor space characterization is to determine the actual lower flammability limit of these tanks, accurately measure low baseline gas release concentrations, and to determine potential hazards associated with larger Gas Release Events (GREs).

The instruments to be installed in the Gas Characterization System (GCS) for vapor monitoring will allow accurate analysis of samples from the tank vapor space. It will be possible to detect a wide range of hydrogen from parts per million (ppm) to percent by volume, as well as other gas species suspected to be generated in waste tanks.

\section{$1.2 \quad$ SCOPE}

This document describes the design of the GCS gas sampling and analysis systems, as well as the systems needed to support operation. Two dual column gas chromatographs (GC), and one Fourier transform infrared spectrometer (FTIR) will be the analytical instruments employed to provide the vapor space gas monitoring for hydrogen and other gas species suspected to be generated in waste tanks, such as nitrous oxide $\left(\mathrm{N}_{2} \mathrm{O}\right)$, ammonia $\left(\mathrm{NH}_{3}\right)$, and methane $\left(\mathrm{CH}_{4}\right)$.

\subsection{FUNCTIONS AND DESIGN REQUIREMENTS}

The primary function of the GCS is to provide an environmentally controlled facility to sample the 241-AN-105 and 241-AW-101 exhaust duct gases and analyze the sampled gases for hydrogen as well as other suspected gas species, which include, but are not limited to methane, nitrous oxide and ammonia. Currently of the 177 radioactive waste tanks on the Hanford Project 
site, twenty five (6 Double Shell and 19 Single Shell Tanks) were identified as having the potential for the buildup of gases to a flammable level. Of these 25 waste tanks, AN-105 and $\mathrm{AW}-101$ have been identified as requiring additional characterization. Analyzing the tank vent gases is required to determine the magnitude and time dependence of the various gases released from these tanks.

The general equipment requirements include sensor operational lifetimes, with periodic preventative maintenance, of at least one year based upon vendor data. The equipment was selected on a best available technology basis to provide usable and traceable analytical data.

The GCS data system will store and archive analytical gas monitoring data, as well as process variables such as temperature and pressure.

The engineering tasks will comply with the requirements specified in WHC-SD-WM-ETP-143, TWRS Hydrogen Mitigation Gas Characterization System Design and Fabrication Engineering Task Plan.

\subsection{SYSTEM CLASSIFICATION}

This system is classified as General Service in accordance with the requirements of HNFPRO-704, Hazards and Accident Analysis Process. Although the GCS function is not safety class or safety significant, its connection with the tank vapor space does demand potential spark source isolation. Defense-in-Depth may necessitate some protective equipment as Safety Equipment List components.

\subsection{TEST FACILITY REQUIREMENTS}

It is necessary to provide a habitable facility to house scientific equipment for the analysis of waste tank vapor space gases. The gas characterization building is similar to the one used for the gas monitoring facility (GMS-2) on SY-101. The analysis for the (GMS-2) shelter installation, structural analysis and seismic analysis for equipment anchorage are presented in WHC-SD-WM-DA-085, 241-SY-101 Gas Monitoring System Design Support Analysis. The facility requirements shall meet the following:

2.2.1 The facility shall be installed in an unprotected area of the waste tank farm.

2.2.2 The facility shall be environmentally controlled in order to maintain the analytical equipment in an acceptable environment. The following external conditions exist:

- air temperature of -23 to $+38{ }^{\circ} \mathrm{C}\left(-10\right.$ to $\left.+100{ }^{\circ} \mathrm{F}\right)$

- relative humidity of 5 to $100 \%$ condensing

- wind speeds up to $31.8 \mathrm{~m} / \mathrm{s}$ (70 miles/hour)

- rain, snow, sleet, lightning, hail, and blowing sand and dust

- radiation up to $100 \mathrm{mr} / \mathrm{hour}$ 


\subsection{SAMPLE GAS DELIVERY SYSTEM REQUIREMENTS}

It is necessary to provide a gas sample delivery system. The gas sample delivery system has the following required features:

2.3.1 Provides the ability to draw a tank gas sample under pressures between -2.99 and $+14.9 \mathrm{kPa}(-12$ and +60 inches of water) and be able to structurally withstand temperatures between -10 and $100^{\circ} \mathrm{C}\left(14\right.$ and $\left.212^{\circ} \mathrm{F}\right)$ and condensed vapors considered to have a pH between 8 and 12 .

2.3.2 Provides the sampled gas from the sample point to the analytical instruments in less than 5 minutes and maintain sample delivery speed upon isolation of any analytical instrument. (The sample gas delivery time analysis is include in Appendix $\mathrm{C}$ in this document.)

2.3.3 Provides two sub-micron sample gas inlet filters inside the GCS building with differential pressure indication.

2.3.4 Provides the capability to isolate individual sample line components, as practical, for maintenance.

2.3.5 Provides the necessary fittings, filters, valves, piping, and sample containers to allow tank vapor space gas samples to be captured and transported to a laboratory for analysis.

2.3.6 Provides manual sample gas flow control, with local flow and pressure indication.

2.3.7 Provides exterior sample gas lines heat traced to maintain a minimum sample temperature of $30^{\circ} \mathrm{C}\left(86^{\circ} \mathrm{F}\right)$ to avoid condensate buildup.

2.3.8 Provides manual sample isolation valves located as close to the tank sample and return points as possible.

2.3.9 Provides manual isolation valves located in the sample system in such a way to minimize large volumes of trapped gas that would dilute the analyzed sample or calibration gases.

2.3.10 Provides equipment arrangement to allow ease of operation with a consideration for system expansion.

2.3.11 Provides HEPA quality filtration of dilute analyzed sample vented to the environment. 


\subsection{SAMPLE GAS ANALYTICAL SYSTEM REQUIREMENTS}

Process instrumentation, such as flow, pressure, and temperature shall be provided in the following accuracies:

\begin{tabular}{||c|c||}
\hline Measured Parameter & Accuracy \\
\hline \hline Temperature & $\pm 2{ }^{\circ} \mathrm{C}$ \\
\hline Absolute Pressure & $\pm 1 \%$ of Full Scale \\
\hline Differential Pressure & $\pm 1 \%$ of Full Scale \\
\hline Flow Rate & $\pm 10 \%$ of Full Scale \\
\hline
\end{tabular}

The sample gas analytical system shall consist of two dual column gas chromatographs and one Fourier transform infrared (FTIR) spectrometer with the following measurement ranges and accuracies for a gaseous mixture consisting primarily of moist air with concentrations of gases listed below:

\begin{tabular}{|c|c|c|}
\hline Measured Gas & Range & Accuracy \\
\hline \multirow{2}{*}{$\mathrm{H}_{2}$} & $3-30 \mathrm{ppm}$ & $\pm 3 \mathrm{ppm}$ \\
\cline { 2 - 3 } & $30-30,000 \mathrm{ppm}$ & $\pm 10 \%$ of Reading \\
\hline \multirow{2}{*}{$\mathrm{CH}_{4}$} & $10-100 \mathrm{ppm}$ & $\pm 10 \mathrm{ppm}$ \\
\cline { 2 - 3 } & $100-30,000 \mathrm{ppm}$ & $\pm 10 \%$ of Reading \\
\hline \multirow{2}{*}{$\mathrm{NH}_{3}$} & $3-30 \mathrm{ppm}$ & $\pm 3 \mathrm{ppm}$ \\
\cline { 2 - 3 } & $30-10,000 \mathrm{ppm}$ & $\pm 10 \%$ of Reading \\
\hline \multirow{2}{*}{$\mathrm{N}_{2} \mathrm{O}$} & $10-30 \mathrm{ppm}$ & \pm 3 ppm \\
\cline { 2 - 4 } & $30-30,000 \mathrm{ppm}$ & $\pm 10 \%$ of Reading \\
\hline
\end{tabular}

The gas grab sample system will allow a selected gas sample to be captured and taken to a laboratory for independent analysis.

Local displays of analyzed gas samples shall be provided, as well as local and remote data logging capabilities through a high speed data link. 


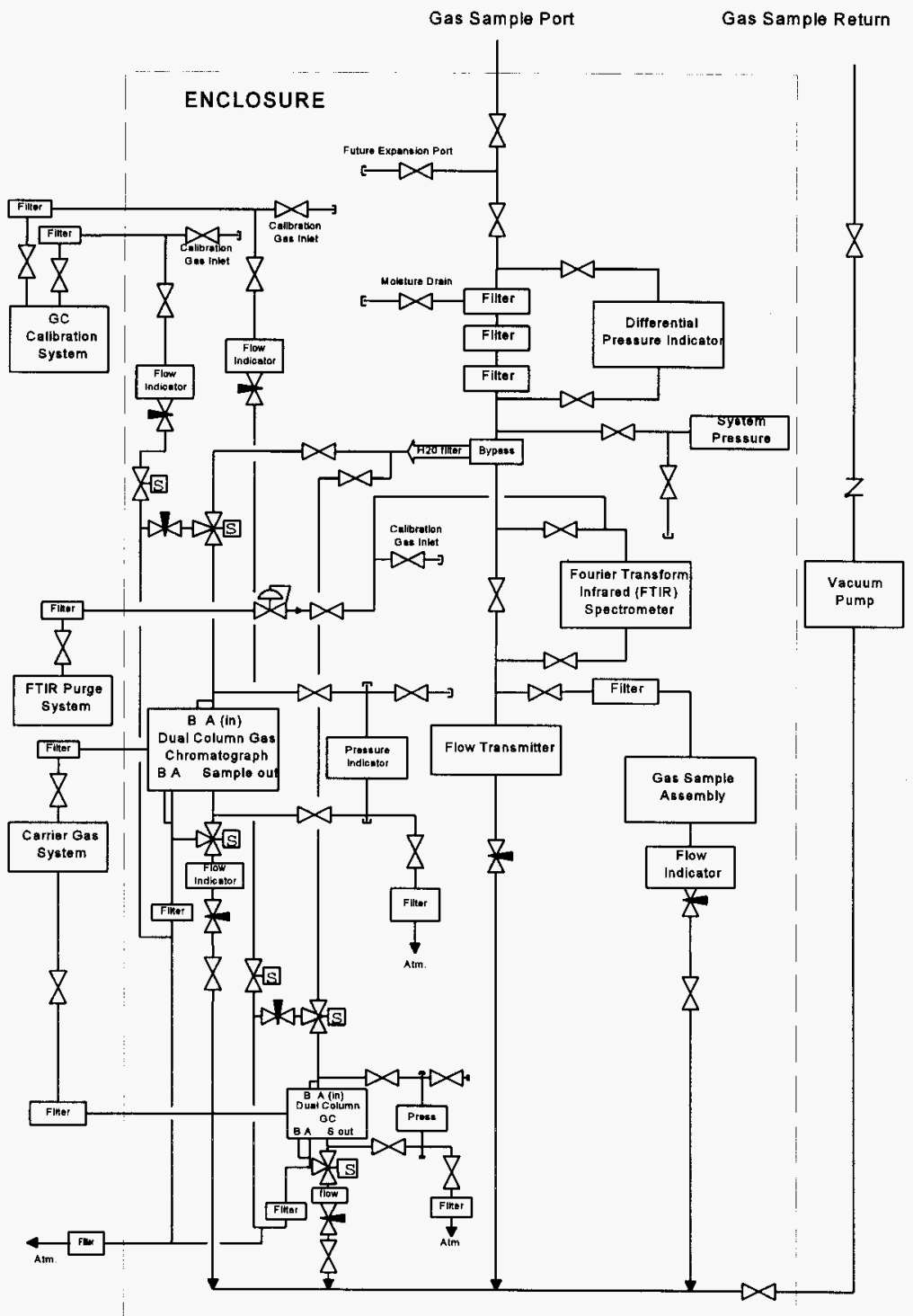

Figure 1 - SYSTEM BLOCK DIAGRAM 


\subsection{DESIGN DESCRIPTION}

The GCS design includes several major subsystems which make up the AN-105 and AW101 exhaust header gas monitoring and analysis system (see Figure 1). The system PI\&D presented on $\mathrm{H}-14-100435$ functionally depicts the overall system.

The gas sampling pneumatic system is composed of tubing, valves, filters, and a vacuum pump which delivers the sample to the analytical instruments.

The sampling process instrumentation includes process temperature, pressure, and flow instruments to characterize the sample being delivered.

- The five analytical instruments (the two dual column GCs and the FTIR) perform the actual measurement and display and then transmit the analyzed gas and process data to the data system file server for access by the designated review teams.

The calibration gas system provides standard gases to the analytical instruments to validate that the data being obtained is accurate.

The nitrogen or air purge gas system allows the FTIR to obtain a background level prior to its validation and operation.

The grab sample system provides the on-line capability to obtain an independent analysis of the tank gas sample.

The power distribution system is composed of 1) unconditioned AC power for lighting, HVAC and system support equipment; 2) conditioned $\mathrm{AC}$ power for the instrumentation systems, including the local GC, FTIR, and data computer systems.

The sample line heat trace system ensures that the sample vapors do not condense (or freeze) within the sample tubing before or following analysis.

- The facility HVAC system provides the condensate protection internal to the shack. The HVAC system also maintains the shack ambient temperature within the analytical instruments' specified operating range, minimizing the data errors due to temperature variations.

\subsection{GAS SAMPLING PNEUMATIC SYSTEM}

The gas sampling pneumatic system includes all the components that deliver the sample to the analytical instruments and return the sample to the tank exhaust header. 


\subsubsection{System Tubing}

The system tubing is 300 series stainless steel in order to withstand the potentially corrosive gases being sampled. The main sample delivery line between the tank exhaust duct and the GCS building is $1.27 \mathrm{~cm}(1 / 2 \mathrm{inch})$ diameter to allow rapid sample transport and to present a reasonable surface area to volume ratio to minimize plating of gas components on the tubing walls. The sample branch tubing was sized for proper interface to the instruments while maintaining the sample delivery rate and minimizing volumes which trap sample or calibration gases.

\subsubsection{System Isolation Valves}

The sample isolation valves $(\mathrm{SV}-* 01, \mathrm{SV}-* 04, \ldots)$ are constructed of 300 series stainless steel. Ball valves are selected to provide minimal flow restrictions in the gas sample lines as well as positive indication of valve position during system operation. Instrumentation isolation valves are provided to allow in-place instrument calibration.

\subsubsection{Sample Inlet Filter System}

Three sample inlet filters are provided to reduce the potential for system contamination. The first filter (FLT-*10) is utilized to trap moisture and particles of 25 microns or larger. The next two filters (FLT $-* 11$, FLT $-* 12$ ) are designed to individually trap particles of 0.2 microns and larger at a $99.9 \%$ efficiency at the planned system flow rates. A differential pressure gauge (PDI-*10) with isolation valves (SV-*6,-*7,-*8,-*9) are installed across the inlet filter to monitor for plugging.

\subsubsection{Gas Chromatograph Sample Gas Loops}

The main sample line is routed near the GC instrument rack in order to provide rapid sample delivery to each instrument. The individual GC sample lines are provided with isolation valves (SV-*20, SV-*27, SV-*30, SV-*37). The $0.3175 \mathrm{~cm}(1 / 8 \mathrm{inch})$ sample lines are reduced to $0.1588 \mathrm{~cm}(1 / 16 \mathrm{inch})$ at the instrument rack bulkhead connectors. The $0.1588 \mathrm{~cm}(1 / 16$ inch) lines provide for flexibility in order to slide the GCs out of the rack for maintenance without disconnecting the gas lines. The sample line instrumentation will be discussed in section 3.2.

\subsubsection{FTIR Sample Gas Loops}

The main sample line is routed through the FTIR sample gas cell (NE-*40) downstream of the $\mathrm{GC}$ sample points. Isolation valves (SV-*40, $\left.\mathrm{SV}_{-} * 41\right)$ are provided in order to remove the sample cell for maintenance or exchange. A bypass line and isolation valve (SV-*12) is provided to allow normal sample flow during the FTIR cell maintenance. Flexible stainless lines are connected to the sample cell to minimize cell vibration, and aid in minor cell movement and maintenance. A cell pressure relief valve (PRV-*40) is provided to prevent cell over pressurization. The relieved gases vent to the environment through HEPA quality depth filters (FLT-*40 and FLT-*41). The associated process instrumentation will be discussed in Section 3.2 . 


\subsubsection{Sample Flow Control Valve}

The main sample line includes a 300 series stainless steel laminar flow element (FE-*10) and flow control valve (SV-*13). The manual flow control valve will be used to adjust the flow to the desired rate as measured by the flow element. Since the system has a dedicated sample pump, the manual valve provides adequate flow control for the GC and the FTIR systems. The associated flow instrumentation will be discussed in section 3.2 .

\subsubsection{Sampling Vacuum Pump}

The sampling pump (P-*10) is a completely sealed stainless steel bellows pump with stainless steel valves and viton valve seats. The pump is designed to transport the sample in a closed loop system. All electrical connections are isolated from the sample stream allowing it to pump potentially hazardous and flammable gases.

\subsubsection{Sample Exhaust Backflow Preventer}

The sample exhaust backflow preventer (SV-*19) is installed in the sample gas return line downstream of the pump. The pump returns the sample gases to the AN-105 and AW-101 tank exhaust header at the same point as the Standard Hydrogen Monitoring System (SHMS). The sample pump can develop in excess of $276 \mathrm{kPa}$ ( $40 \mathrm{psi}$ ) outlet pressure with an obstruction in the outlet line. The purpose of the backflow preventer is to reduce the possibility of other gases flowing back into the GCS sampling loop during a faulted condition.

\subsection{GAS SAMPLING INSTRUMENTATION SYSTEMS}

The gas sampling instrumentation systems include the sample gas process instruments, the gas analysis and signal conditioning, and data analysis, storage and transmission. The accuracies listed in this section are limited to the individual instruments. Total system accuracy must include dropping resistor accuracies, temperature effects, readout and data logger accuracies.

\subsubsection{Main Sample Line}

The main sample gas line process instruments provide inlet filter differential pressure, sample inlet pressure and flow indication.

\subsubsection{Inlet Filter Differential Pressure}

A differential pressure indicator (PDI-*10) is installed across the filters to provide guidance on when to maintain the filters. When a pressure drop of $13.7 \mathrm{kPa}\left(55^{\prime \prime} \mathrm{H}_{2} \mathrm{O}\right)$ or greater is indicated across the filters, the filter elements should be replaced to minimize the potential migration of contaminates through the filters. The gauge is rated up to an ambient operating temperature of $93^{\circ} \mathrm{C}\left(200^{\circ} \mathrm{F}\right)$. The differential pressure range is 0 to $14.9 \mathrm{kPa}\left(0\right.$ to $\left.60^{\prime \prime} \mathrm{H}_{2} \mathrm{O}\right)$. The accuracy is $\pm 2 \%$ (ascending). 


\subsubsection{Sample Inlet Pressure}

The inlet pressure indicating transmitter (PIT-*10) monitors the sample gas delivery pressure in the range of 0 to $207 \mathrm{kPa}$ ( 0 to 30 psia) with an accuracy of $\pm 0.1 \%$ of span. The process gases are isolated from the signal conditioning of the transducer by a stainless steel process diaphragm, a capillary of silicon fluid, and a second transducer diaphragm.

\subsubsection{Sample Flow Indication}

The sample flow measurement is obtained using a stainless steel laminar flow element (FE-*10) and a differential pressure indicating transmitter (FIT-*10). The flow indicating transmitter has a range of 0 to $2.49 \mathrm{kPa}$ ( 0 to 10 inches of water) with an accuracy of $\pm 0.2 \%$ span and construction equal to that of the absolute pressure transducer. The flow element provides a differential pressure of 0 to $1.99 \mathrm{kPa}$ ( 0 to 8 inches of water) for a flow of nominally 0 to $0.757 \mathrm{SL} / \mathrm{S}$ (0 to $1.6 \mathrm{SCFM}$ ), and is calibrated to an accuracy of $\pm 1 \%$ of full scale.

\subsubsection{Gas Chromatograph Instrumentation}

The GC instrumentation includes the chromatograph columns and detectors, the signal and control processor, process differential and absolute pressure transmitters, and sample flow control and indication. The two dual column GCs each have different range and/or species of gas monitoring. The first GC (NT-*20) is configured to measure hydrogen. The first column measures hydrogen in the range of 3 to $3,000 \mathrm{ppm}$ by volume and the second measures hydrogen in the range from 300 to $30,000 \mathrm{ppm}$ hydrogen by volume.

The second GC (NT-*30) is configured to measure a wide range of gas species including but not limited to nitrous oxide $\left(\mathrm{N}_{2} \mathrm{O}\right)$ and methane $\left(\mathrm{CH}_{4}\right)$. The first column measures $\mathrm{N}_{2} \mathrm{O}$ in the range from 3 to $3,000 \mathrm{ppm}$ and $\mathrm{CH}$ in the range from 10 to $5,000 \mathrm{ppm}$. The second column measures $\mathrm{N}_{2} \mathrm{O}$ in the range from 300 to $30,000 \mathrm{ppm}$ and $\mathrm{CH}$ in the range from 300 to 30,000 ppm. All of the GCs will be calibrated in place using standard calibration gases, to be discussed in the Calibration, Carrier, and Purge System section of this document.

Even though the low and high range columns are specified differently, there should be good agreement between the columns even below 100ppm.

\subsubsection{Chromatograph Columns and Detector}

The GC sample gas system utilizes $0.1588 \mathrm{~cm}(1 / 16 \mathrm{inch})$ and smaller stainless steel tubing to contain the process sample gas and the associated carrier gas. The sample gas valve is controlled by the system and automatically switches the sample gas from a standard volume into the detector columns, for a controlled time, and drives it through the columns with the carrier gas. At a prescribed time, the detector analyzes the gas exiting the column. The GC monitoring for the high and low levels of hydrogen uses a molecular sieve column and a Thermal Conductivity Detector (TCD) while the GC monitoring for the low and high levels of methane and nitrous oxide utilizes a poraPLOT $\mathrm{Q}$ column and a thermal conductivity detector. 


\subsubsection{Differential Pressure}

A differential pressure transducer measures the pressure drop across each GC. The differential pressure indicating transmitters (PDIT-*20, PDIT-*30) have a range of -17 to $45 \mathrm{kPa}$ ( -70 to 180 inches of water) with an accuracy of $0.2 \%$ of span. The process gases are isolated from the signal conditioning of the transducer by a stainless steel process diaphragm, a capillary of silicon fluid and a second transducer diaphragm. Proper positioning of the manual valves associated with the PDITs will also allow the GC inlet pressures to be monitored. It is important to maintain similar inlet pressures during tank gas and calibration gas sampling to assure accurate comparison of the gas analysis.

\subsubsection{Sample Flow Control and Indication}

The GC sample flow indication and control is accomplished by small purge rotameters with integral flow control valves. The flow indicators (FI-*20, FI-*30) and control valves (SV$* 26, \mathrm{SV}-* 36$ ) are located downstream of the GCs in order to keep the sample gas pressure as close to atmosphere as possible. The purge meters have a range of $0-46 \mathrm{cc} / \mathrm{min}$ and an accuracy of $\pm 10 \%$ of full scale.

\subsubsection{FTIR Instrumentation}

The FTIR instrumentation includes the infra-red light source and detection system, the signal processor, the detection cell sample gas temperature measurement, the detection cell sample gas absolute pressure measurement, and the sample gas flow measurement. The FTIR system is used to detect and analyze a wide range of gas species including but not limited to nitrous oxide $\left(\mathrm{N}_{2} \mathrm{O}\right)$, ammonia $\left(\mathrm{NH}_{3}\right)$, and carbon dioxide $\left(\mathrm{CO}_{2}\right)$. The FTIR and one of the dual column GCs may be used to compliment the data taken on the wide range of gas species; however, the FTIR is only required to report data on ammonia analysis.

\subsubsection{Light Source and Detection System}

The FTIR uses a ceramic infrared light operating in the mid-infrared region as a light source for an interferometer (an optical device for determining the wavelength of light). The light passes through the sample gas and creates an interference pattern on a pyroelectric detector. This pattern is unique for each different gas component. A helium-neon laser is used as a reference signal for optical alignment and pathlength verification.

\subsubsection{Signal Processing System}

Analog-to-digital converters process the detector signal to a form that the FTIR computer can use. The computer controls a movable mirror in the interferometer cavity to determine the light intensity versus wavelength (absorption spectra). The FTIR computer displays the spectrum of the gas sample on its screen using vendor supplied software and can send the data to the GCS Data System upon request via an RS-232 digital communications line or ethernet. 


\subsubsection{Cell Sample Gas Temperature}

The cell sample gas temperature monitor combines an RTD (TE-*40) and an accurate signal conditioner with a local digital readout (TIT-*40) and provides a 4-20 mA analog output. The RTD is encased in a series 316 stainless steel welded jacket, which provides a protective barrier between the RTD and the potentially hazardous sample gas.

The accuracy of the RTD is $\pm 0.15 \%+0.002 \mathrm{X}{ }^{\circ} \mathrm{C}$ (actual temperature).

The accuracy of the readout transmitter is $\pm 0.2{ }^{\circ} \mathrm{C} \pm 1 / 2$ least significant digit (LSD).

\subsubsection{Cell Sample Gas Absolute Pressure}

The FTIR cell sample pressure indicating transmitter (PIT-*40) monitors the sample gas pressure in the range from 0 to $207 \mathrm{kPa}$ absolute ( 0 to $30 \mathrm{psia}$ ) with an accuracy of $\pm 0.1 \%$ of span. The process gases are isolated from the signal conditioning of the transducer by a stainless steel process diaphragm, a capillary of silicon fluid and a second transducer diaphragm.

\subsubsection{Sample Gas Flow Indication}

The FTIR sample gas flow indicator and transmitter are the same devices discussed in 3.2.1.3 above, since the main sample flow passes through the FTIR cell.

\subsubsection{Process Instrumentation/Data Logger Interfaces}

The process instrumentation, monitoring pressure, temperature and flow, is interfaced to the GCS Data System via 4-20 mA current loops and discrete contact closures through A/D cards and direct digital input cards in the data system. The analytical instrumentation utilizes digital data links to transmit their processed data to the GCS data system for display and recording.

\subsection{CALIBRATION, CARRIER, AND PURGE GAS SYSTEM}

The calibration, carrier, and purge gas system is configured into four sections which include the automatic GC calibration gas supply, the manual GC and FTIR calibration gas supply, the GC carrier gas supply, and the FTIR manual purge gas supply. All of the gases used in conjunction with the GCS systems are certified specialty mixed gases.

\subsubsection{Automatic Calibration Gas Supply}

The automatic GC calibration gas supply utilizes two standard gas bottles mounted in the local bottle rack adjacent to the GCS building. The bottle regulators (PCV-*61, PCV-*63) are set to a prescribed low psi value determined empirically, in conjunction with the manual calibration gas metering valves and flow meters (FIV-*20, FIV-*30), to provide a constant gas bypass flow of nominally $470 \mathrm{cc}$ per minute $(1 \mathrm{CuFt} / \mathrm{Hr})$ passed a calibration gas sample volume. Flow 
control valves (SV-*21, SV-*31) adjust the GC calibration gas inlet pressure and flow to be consistent with the tank sample gas inlet pressure and flow conditions.

The manual isolation valves (SV-*61, SV-*63, SV-*28, SV-*38) are normally open to allow the calibration gas to flow to the selected GC as directed by the electrically controlled isolation valves. The selected GC isolation valves (SOV-*20, SOV-*30) are controlled in conjunction with the GC sample source selection valves (SOV-*21, SOV-*31) by the data system, when the system performs a routine automatic calibration. When the calibration is complete, the electrically controlled isolation valve is closed and the sample source selection valve is switched to again permit tank sample gas to flow through the GC.

\subsubsection{Manual Calibration Gas Supply}

The manual GC calibration gas is supplied in small, portable, low pressure lecture bottles that are pressure regulated to nominally the same pressure as the automatic calibration gas system. A set of isolation valves (SV-*29, SV-*39, SV-*49) direct the pressure regulated standard gases to the selected instrument to be calibrated. The calibration gas bottle is connected to the regulator (PCV-*65) and associated isolation valve (SV-*69) and then to the appropriate instrument isolation valve via a flexible stainless steel metal hose. The operator directs the electrically controlled isolation and gas selection valves to open via the data system keyboard.

The manual FTIR calibration gas is supplied in large full sized bottles positioned outside the enclosure. A wall penetrating 1/4 inch stainless steel tube and flexible stainless steel metal hose provides the interface to the FTIR cell isolation valve (SV-*49). The operator provides tank sample gas isolation to the cell by closing the cell isolation valve (SV-*40) and then regulates the calibration gas flow and cell pressure, after opening isolation valve (SV-*49), to simulate normal operating conditions. The FTIR ammonia calibrating gas cannot be delivered to a static cell, since the ammonia will attach itself to the cell walls and provide erroneous analysis values. Following analytical validation checks, the isolation valves are positioned to return tank gas sample flow.

\subsubsection{Carrier Gas Supply}

The GC carrier gas supply is provided through two manifolds in the gas bottle rack adjacent to the GCS building. Each manifold supports two bottles of gas and a single pressure regulator. The manifold pressure regulators (PCV -*60, PCV-*62) and the internal GC pressure control valves control the carrier gas pressure to supply the required carrier gas flow for each of the GCs. It is imperative that the carrier gas continue to flow in the GCs during gas bottle change out to maintain the operating conditions. The selected carrier gases are helium for gas species other than hydrogen, and nitrogen for the GCs monitoring for hydrogen.

\subsubsection{FTIR Purge Gas Supply}

The FTIR purge gas supply is also the high purity nitrogen carrier gas for the hydrogen detection GC and is provided by pressure regulator (PCV-*64). The bottles of high purity nitrogen are located in the gas bottle rack adjacent to the GCS building. The purging of the FTIR 
is performed in conjunction with the system manual calibration and provides a zero background reference for the FTIR system performance validation. The purge gas is isolated from the FTIR chamber through a single isolation valve (SV-*48). The FTIR chamber is purged by first isolating the sample gas inlet valve (SV-*40), and then alternately evacuating the chamber via the sample pump, and purging with the nitrogen bottle gas.

\subsection{GCS POWER DISTRIBUTION}

The GCS AC power is supplied from the $75 \mathrm{kVA} 240 / 120$ VAC single phase transformer located for the selected tank per the appropriate installation drawings. The AC power distribution within the GCS is defined on the system Electrical One-Line Diagram, H-14-100436. There is only one source of AC power to the GCS, but power conditioning is provided to support the GCS systems. Facility $240 / 120$ VAC power supports the HVAC, lighting, gas sample pump, sample line heat trace, and convenience outlets. Conditioned power, provided by a noise reduction isolation transformer, provides power for all the analytical and process instrumentation including the computer systems and the 24 VDC power supply for the loop powered instruments and discrete contacts that interface the data system $\mathrm{I} / \mathrm{O}$ cards.

\subsubsection{Building AC Power Distribution}

The GCS will be supplied 240/120 VAC single phase power to a 200 ampere distribution panel (DP-*10). The electrical one-line diagram, H-14-100436, defines the distribution from the main entrance panel, instrumentation isolation transformer, and other individual power loads.

Unconditioned power is supplied to the following:

- Interior lights and receptacles.

- $\quad$ Exterior lighting and GFI receptacles.

- HVAC.

- $\quad$ Sample line trace heat.

- $\quad 7.5 \mathrm{~kW}$ stepdown isolation transformer

- $\quad$ GCS sample pump

\subsubsection{Conditioned AC Power Distribution}

Conditioned AC power in the GCS is provided through an instrumentation isolation transformer. The isolation transformer provides power for all the facility analytical and process instrumentation.

\subsubsection{Instrumentation DC Power Distribution}

The instrumentation DC power supply (PS-*10) provides a maximum of 2 amperes at 24 VDC for loop powered process instrumentation and process alarm contact interface into the A/D and digital I/O cards located in the GCS data system. 


\subsection{HEAT TRACE AND ENVIRONMENTAL CONTROL}

The GCS must operate during all seasons on the selected tank farm without additional environmental protection. It is a requirement that the system provide the gas sample to the analytical equipment without being condensed in the delivery tubing. Sample tube heat trace is designed to provide a dry sample to the analytical equipment over the expected exterior ambient temperature range. Since the analytical equipment must be able to perform during wide outside ambient temperature conditions, an insulated building with an HVAC system has been utilized to house the instrumentation.

\subsubsection{Sample Gas Line Heat Trace Control and Monitoring}

Between the exhaust header and the GCS instrumentation, the main sample gas line utilizes prefabricated heat traced and insulated $1.27 \mathrm{~cm}(1 / 2 \mathrm{inch})$ stainless steel tubing. The tubing is insulated and is heat traced at $0.33 \mathrm{Wat} / \mathrm{cm}$ (10 watts per foot). The analysis in Appendix A of WHC-SD-WM-SDD-001, Standard Hydrogen Monitor System Design Description, shows that the heat trace will raise the sample gas to an operating temperature of $21^{\circ} \mathrm{C}\left(70^{\circ} \mathrm{F}\right)$ in $457.2 \mathrm{~cm}(15$ feet) of tubing at a sample flow of $0.71 \mathrm{SL} / \mathrm{s}(1.5 \mathrm{SCFM})$ at a worst case sample gas temperature of $-1{ }^{\circ} \mathrm{C}\left(30^{\circ} \mathrm{F}\right)$ and ambient temperature of $-29^{\circ} \mathrm{C}\left(-20^{\circ} \mathrm{F}\right)$. It is assumed that the dew point of the sample gas on the warmest day would not exceed $21^{\circ} \mathrm{C}\left(70^{\circ} \mathrm{F}\right)$.

The heat trace controller (TIC-*10) provides a local digital temperature display and is configured for ON/OFF control with a minimum deadband of $2{ }^{\circ} \mathrm{F}$. The controller's second setpoint (TSL-*10) will provide low temperature alarm contacts to be interfaced to the GCS data system. The temperature feedback is provided through a single type $\mathrm{K}$ thermocouple (TE-*10) that is nominally located $122 \mathrm{~cm}$ (4 ft) upstream of the sample gas entrance into the GCS building. The GCS HVAC will maintain the sample temperature while in the building and the additional heat trace between the GCS building, sample pump and the exhaust duct supply or return port will provide adequate additional heating to maintain the sample gas above dew point.

\subsubsection{Building HVAC Control and Monitoring}

The GCS building is equipped with an HVAC unit (ACU-*10) which provides cooling in the summer and heating in the winter. The HVAC unit is equipped with a thermostat for controlling the desired temperature. Room ambient temperature monitoring, display and transmission will be provided by an RTD (TE-*11) and signal conditioner with a local digital readout (TIT-*11) and a 4-20 mA analog output to interface the GCS data system I/O to provide remote temperature logging. The accuracy of the RTD is $\pm 0.15 \%+0.002 \mathrm{X}^{\circ} \mathrm{C}$ (actual temperature). The accuracy of the readout transmitter is $\pm 0.2^{\circ} \mathrm{C} \pm 1 / 2 \mathrm{LSD}$. 


\subsection{SYSTEM LIMITATIONS AND RESPONSE TO CASUALTY EVENTS}

The gas monitoring system contains the sampled gas in stainless steel for the duration of its path outside the tank vapor space. The sampling system uses a vacuum pump to draw the gas from the tank exhaust duct and return it to the common AN-105 and AW-101 tank vent header. The entire system is under a vacuum as provided by the tank ventilation system and the sampling system. These two barriers, the stainless steel and vacuum, provide the containment for the monitoring system sample gas. The following paragraphs identify postulated system limitations and casualty events and potential responses.

\subsection{BREACH OF SAMPLING SYSTEM CONTAINMENT}

The failure of the sampling system stainless steel containment components would provide a path to atmosphere. Since the system will be initially leak checked with pressure, and routinely checked during its operational life, the only credible path to atmosphere would be from an improper valve operation.

The result of an open valve upstream of the sample pump would be to allow inflow of atmosphere to dilute the sample gas providing erroneous data from the analytical instruments. This will be managed administratively.

The result of a disconnected or broken sample return line downstream of the sample pump would result in waste tank vapor being vented directly to atmosphere. Although this would be undesirable, the sample stream inlet to the GCS is filtered through two 0.2 micron particulate filters connected in series which removes smaller particle sizes and is more efficient than the exhaust duct HEPA filter system. This will be managed administratively.

\subsection{TOTAL LOSS OF FACILITY POWER}

Total loss of facility power will terminate the sampling system operation. Gas monitoring will be suspended until power is restored.

\subsection{SAMPLE PUMP FAILURE}

Sample pump failure will terminate the sampling system flow. The sample flow process signal to the GCS data system will provide the operator a low flow indication of pump failure. The gas monitoring will be suspended until the pump operation is restored.

\subsection{LOSS OF FACILITY HVAC}

Loss of facility HVAC will affect the quality of the analytical system data. A prolonged outage may require the system equipment power to be removed. The operation of the gas monitoring system will be administratively controlled during loss of HVAC. 


\subsection{OPERATION}

The operation of the GCS will permit the continual sampling and monitoring of the waste tank gases. Accurate gas analysis will allow determination of the actual lower flammability limit of the selected tanks, accurately measure low baseline gas release concentrations, and determine potential hazards associated with larger Gas Release Events.

\subsection{SYSTEM STARTUP}

The system startup is a major evolution in the system operation. Startup is composed of many administratively and procedurally controlled subtasks. The following provides a proposed sequence of events for those subtasks. (It should be noted that a functional leak check may be performed at any time following system energization.)

5.1.1 Verify that the facility system power is available.

5.1.2 Energize the HVAC system and establish the facility environmental control to $24 \pm$ $3{ }^{\circ} \mathrm{C}\left(75 \pm 5^{\circ} \mathrm{F}\right)$.

5.1.3 Verify the position of all the manual valves.

5.1.4 Energize each of the powered instruments and verify nominal indications.

5.1.5 Adjust the sample gas heat trace control. Energize the heat trace power and verify that the sample line is controlling to setpoint.

5.1.6 Verify that the manual sample line valves are properly positioned and start the sample pump. (Should be performed in conjunction with the associated SHMS sample line flow.)

5.1.7 Adjust the main sample flow control valve (SV-*13) for the required flow. Verify the following sample flow parameters are acceptable:

- Proper flow indication on FIT-*10.

- Proper range of sample line absolute pressure as indicated on PIT-*10 and PIT-*40.

- Proper differential pressure indicated across the inlet filter as indicated on PDI-*10.

- Proper temperature indication on the FTIR gas temperature indicating transmitter TIT-*40. 
5.1.8 Adjust the appropriate carrier gas bottle pressures for each of the dual column GCs.

5.1.9 Establish the sample gas flows in each of the GCs using the appropriate flow indicator and integral flow control valve. Verify the following parameters are acceptable.

- GC differential pressure is indicating within bounds.

- GC inlet pressure is indicating within bounds.

5.1.10 Adjust the automatic calibration gas bottle pressures and gas flows for each of the GC columns.

5.1.11 Verify that the process and analytical instrumentation signals are being transmitted and received by the GCS data system.

\subsection{PERFORM A FUNCTIONAL VALIDATION ON EACH GAS CHROMATOGRAPH}

The two dual column GCs will require a functional validation on a routine basis. The procedure may require Maintenance, Operations and laboratory support personnel. The manually installed, portable calibration gas bottles will be used to inject standard gases at a selected pressure for this validation. It will be important to follow the validation procedures closely to assure consistent results from the equipment.

\subsection{PERFORM A FUNCTIONAL VALIDATION ON THE FTIR}

The FTIR will require a functional validation on a routine basis. The procedure may require Maintenance, Operations and laboratory support personnel. The manually installed, portable calibration gas bottles will be used to inject standard gases at a selected pressure for this validation. It will be important to follow the validation plan closely to assure consistent results from the equipment. The data will be compared to a HITRAN spectral library data base for validation.

\subsection{PERFORM A ROUTINE SYSTEM LEAK CHECK}

It will be necessary to perform a routine system leak check, especially after any sample loop components have been removed or replaced. The leak check will utilize the sample pump to generate the vacuum, and the system absolute pressure gauges will provide the indication for leak evaluation. If the system is found to have a leak, portions of the system will be isolated until the leak can be identified and corrected. 


\subsection{MAINTENANCE}

The GCS including the facility support equipment, gas sample delivery system, analytical instrumentation, and data processing and transmission equipment will require routine maintenance to support continual operation. Detailed maintenance procedures will cover the general maintenance activities. Some of the maintenance activities, such as the calibration of the GCs and FTIR, will be performed by laboratory support, Operations, and Maintenance personnel. The following is a general listing of maintenance operations.

6.1 Manual calibration of each gas chromatograph system using standard gases (NT$* 20$, NT-*30).

6.2 Manual validation of the FTIR spectrometer system using standard gases, with the results compared to the HITRAN data base (NT-*40).

6.3 Calibration of the gas sample inlet absolute pressure transmitter (PIT-*10).

6.4 Calibration of the input filter differential pressure gauge (PDI-*10).

6.5 Calibration of each GC differential pressure transmitter (PDIT-*20, PDIT-*30).

6.6 Calibration of the FTIR absolute pressure transmitter (PIT-*40).

6.7 Calibration of the FTIR temperature readout and transmitter (TIT-*40).

6.8 Calibration of the main sample flow differential pressure transmitter (FIT-*10).

6.9 Calibration/verification of the gas sample line heat trace control, readout, and low temperature alarm (TIC-*10, TSL-*10).

6.10 Calibration of the facility temperature readout and transmitter (TIT-*11).

6.11 Functional verification of each GC sample gas flow indicator (FI-*20, FI-*30).

6.12 Functional verification of the electrically operated calibration gas isolation valves (SOV-*20, SOV-*30).

6.13 Draining of or replacement of any sample line input filters.

6.14 Replacement or cleaning of the air conditioner evaporator cooling air filter. General HVAC preventative maintenance.

6.15 Routine replacement of carrier and calibration gas bottles.

6.16 Routinely, as required, bake out the GC columns and re-establish proper analytical methods. 


\subsection{REFERENCES}

\subsection{GENERAL GOVERNMENT AND REGULATORY DOCUMENTS}

7.1.1 DOE Order 6430.1a, "General Design Criteria".

7.1.2 NFPA-70, "National Electrical Code • 1993".

\subsection{HANFORD GENERATED ENGINEERING DOCUMENTS}

7.2.1 WHC-SD-WM-ETP-143, TWRS Hydrogen Mitigation Gas Characterization System Design and Fabrication Task Plan.

7.2.2 WHC-SD-WM-SDD-003, Waste Tank 241-SY-101 Gas Monitoring System 2 System Design Description.

7.2.3 WHC-SD-WM-DA-085, 241-SY-101 Gas Monitoring System Design Support.

7.2.4 WHC-SD-WM-FDC-041, Gas Characterization System Functional Design Criteria. 


\section{APPENDIX A - GCS DRAWING/SUPPORTING DOCUMENT LIST}

\section{GCS DRAWING LIST}

DRAWING NO.

H-2-818214

H-2-818220

H-14-100434

H-14-100435

H-14-100436

H-14-100437

H-14-100438

H-14-100439

H-14-100440

H-14-100441

H-14-100442

H-14-100443

H-14-100444

H-14-100445

H-14-100446

H-14-100447

H-14-100448

H-14-100449

\section{TITLE}

STANDARD-B HYDROGEN MONITORING SYSTEM GAS BOTTLE RACK STANDARD-B HYDROGEN MONITORING SYSTEM SAMPLE PUMP STAND ASSY

WASTE TANK GAS CHARACTERIZATION SYS. DRAWING TREE \& INDEX

WASTE TANK GAS CHARACTERIZATION SYS. PIPING \& INSTR DIAGRAM

WASTE TANK GAS CHARACTERIZATION SYSTEM ONE-LINE DIAGRAM

WASTE TANK GAS CHARACTERIZATION SYSTEM ELEMENTARY DIAGRAM

WASTE TANK GAS CHARACTERIZATION SYSTEM ASSEMBLY

WASTE TANK GAS CHARACTERIZATION SYSTEM INSTR/VALVE PANEL ASSEMBLY

WASTE TANK GAS CHARACTERIZATION SYSTEM GC CABINET ASSEMBLY

WASTE TANK GAS CHARACTERIZATION SYSTEM COMPUTER CABINET ASSEMBLY

WASTE TANK GAS CHARACTERIZATION SYSTEM JUNCTION BOX ASSEMBLY

WASTE TANK GAS CHARACTERIZATION SYSTEM WIRING DIAGRAM

WASTE TANK GAS CHARACTERIZATION SYSTEM GC CABINET WIRING DIAGRAM

WASTE TANK GAS CHARACTERIZATION SYSTEM COMPUTER CABINET WIRING DIAGRAM

WASTE TANK GAS CHARACTERIZATION SYSTEM LOOP DIAGRAMS

WASTE TANK GAS CHARACTERIZATION SYSTEM INTERCONNECTION DIAGRAM

WASTE TANK GAS CHARACTERIZATION INSTALLATION

AN FARM WASTE TANK GAS CHARACTERIZATION INSTALLATION 


\section{APPENDIX A (continued) - GCS DRAWING/SUPPORTING DOCUMENT LIST GCS SUPPORTING DOCUMENT LIST \\ DOCUMENT NO. TITLE}

WHC-SD-WM-ETP-143, TWRS Hydrogen Mitigation Gas Characterization System Design and Fabrication Engineering Task Plan

WHC-SD-WM-FDC-041, Gas Characterization System Functional Design Criteria

WHC-SD-WM-ATP-160, Gas Characterization System Shop Acceptance Test Procedure

WHC-SD-WM-ATR-160, Gas Characterization System Shop Acceptance Test Report

WHC-SD-WM-ATP-161, Gas Characterization System 241-AN-105 Field Acceptance Test Procedure

WHC-SD-WM-ATR-161, Gas Characterization System 241-AN-105 Field Acceptance Test Report

WHC-SD-WM-ATP-162, Gas Characterization System 241-AW-101 Field Acceptance Test Procedure

WHC-SD-WM-ATR-162, Gas Characterization System 241-AW-101 Field Acceptance Test Report

WHC-SD-WM-ATP-172, Gas Characterization System Software Acceptance Test Procedure

WHC-SD-WM-ATR-172, Gas Characterization System Software Acceptance Test Report

WHC-SD-WM-SFR-012, Functional Requirements for Gas Characterization System Computer Software

HNF-SD-WM-CSWD-077, Computer Systems and Software Description for Gas Characterization System

VI-22665

System Certified Vendor Information 


\section{APPENDIX B - MAJOR COMPONENTS LIST}

LIST OF COMPONENTS IN THE SAMPLE GAS STREAM:

\section{COMPONENT DESCRIPTION}

FE-*10

FI- $* 20$

FI- $* 30$

FIV-*50

FIT $-* 10$

FLT-*10

FLT-*11

FLT-*12

FLT $-* 13$

FLT $-* 20$

FLT- $* 21$

FLT -23

FLT-*30

FLT $-* 31$

FLT-* 40

FLT-*41

FLT $-* 50$

NE-*40

NT-*20

NT-*30

P-*10

PDI-*10

PIT-*10

PDIT-*20

PDIT-*30

PIT $-* 40$

PRV-*40

SOV $-* 21$

SOV-*22

SOV-*31

SOV-*32

SV-*01

SV-*03

SV-*04

SV_*05

SV-*06

SV-*07

SV-*08

SV-*09

SV-*10

SV-*11

SV-*12

LOW FLOW METER

LOW FLOW METER

25 MICRON FILTER

0.2 MICRON FILTER

0.2 MICRON FILTER

FILTER

FTIR SAMPLE CELL

SAMPLE PUMP

$1 / 2$ " SS BALL VALVE

$1 / 2$ " SS BALL VALVE

$1 / 2$ " SS BALL VALVE

$1 / 8$ " SS BALL VALVE

$1 / 8$ " SS BALL VALVE

1/8" SS BALL VALVE

1/8" SS BALL VALVE

$1 / 8$ " SS BALL VALVE

$1 / 8$ " SS BALL VALVE

$1 / 2$ " SS BALL VALVE
IN-LINE LAMINAR FLOW ELEMENT

LOW FLOW ROTAMETER

DIFFERENTIAL PRESS. TRANSMITTER

0.2 MICRON HI PURITY FILTER

0.2 MICRON HI PURITY FILTER

MOISTURE SEPARATOR

0.2 MICRON HI PURITY FILTER

0.2 MICRON HI PURITY FILTER

0.2 MICRON HI PURITY FILTER

0.2 MICRON HI PURITY FILTER

0.2 MICRON HI PURITY FILTER

GAS CHROMATOGRAPH

GAS CHROMATOGRAPH

DIFFERENTIAL PRESSURE INDICATOR ABS. PRESS INDICATE TRANSMITTER

DIFF.PRESS. INDICATE TRANSMITTER DIFF.PRESS. INDICATE TRANSMITTER ABS. PRESS INDICATE TRANSMITTER $1 / 4$ " ADJ. PRESS. RELIEF VALVE

3 WAY SOLENOID VALVE

3 WAY SOLENOID VALVE

3 WAY SOLENOID VALVE

3 WAY SOLENOID VALVE

1/4" FILTER DRAIN VALVE

\section{VENDOR AND PART NO.}

MERIAM INSTRUMENT, 50MJ10-10

WALLACE AND TIERNAN, 30D016SIXXX WALLACE AND TIERNAN, 30D016SIXXX WALLACE AND TIERNAN, 32E113S1XX3

ROSEMOUNT 3051CD-1A22A1A-B4-E5-M5 GENERANT, 2S500-25

MATHESON, 6134-T8FF

MATHESON, 6134-T8FF

A + CORP., 101-002-SS

NUPRO, SS-4FW-2

MATHESON, 6134-T4FF

MATHESON, 6134-T4FF

NUPRO, SS-4FW-2

MATHESON, 6134-T4FF

MATHESON, 6134-T4FF

MATHESON, 6134-T8FF

FISHERBRAND, 09-753-13C

INFRARED ANALYSIS, 10-PA WITH GOLD

MIRRORS (mod. 5m)

MICROSENSOR TECH. INC., M200D

MICROSENSOR TECH. INC., M200D

PARKER HANNIFIN, MB-302-XP (29678M1)

ORANGE RESEARCH, 1516 DG-1 C-4.5L

ROSEMONT, 3051CA-1A22A1A B4-E5-M5

ROSEMONT, 3051CD-2A22A1A B4-E5-M5

ROSEMONT, 3051CD-2A22A1A B4-E5-M5

ROSEMONT, 3051CA-1A22A1A B4-E5-M5

NUPRO, SS-4-CPA-2-3

HONEYWELL/SKINNER, B14DK1075-110VAC

HONEYWELL/SKINNER, B14DK1075-12VDC

HONEYWELL/SKINNER, B14DK1075-110VAC

HONEYWELL/SKINNER, B14DK1075-12VDC

WHITEY, SS-63TS8

WHITEY, SS-63TS8

WHITEY, SS-63TS8

WHITEY, SS-42S4

WHITEY, SS-41S2

WHITEY, SS-41S2

WHITEY, SS-41S2

WHITEY, SS-41S2

WHITEY, SS-41S2

WHITEY, SS-41S2

WHITEY, SS-63TS8 


\section{LIST OF COMPONENTS IN THE SAMPLE GAS STREAM:(CONT.)}

\section{COMPONENT DESCRIPTION}

SV-*13

SV-*14

SV-*15

SV-*16

SV-*17

SV-*18

SV-*19

SV-*20

SV-*21

SV $-* 22$

SV-*23

SV-*24

SV-*25

SV-*26

SV-*27

SV-*30

SV-*31

SV-*32

SV-*33

SV-*34

SV-*35

SV-*36

SV-*37

SV-*40

SV-*41

SV-*42

SV-*43

SV-*50

SV-*51

TE-*40
$1 / 2$ " BONNET FLOW CONT. VALVE

$1 / 8$ " SS BALL VALVE

$1 / 8$ " SS BALL VALVE

$1 / 8$ " SS BALL VALVE

1/8" SS BALL VALVE

$1 / 2$ " SS BALL VALVE

$1 / 2$ " CHECK VALVE

$1 / 8$ " SS BALL VALVE

1/8" METERING VALVE

$1 / 8$ " SS BALL VALVE

$1 / 8$ " SS BALL VALVE

1/8" SS BALL VALVE

$1 / 8^{\prime \prime ~ S S ~ B A L L ~ V A L V E ~}$

1/8" METERING VALVE

1/8" SS BALL VALVE

1/8" SS BALL VALVE

1/8" METERING VALVE

1/8" SS BALL VALVE

1/8" SS BALL VALVE

$1 / 8$ " SS BALL VALVE

$1 / 8$ " SS BALL VALVE

1/8" METERING VALVE

1/8" SS BALL VALVE

$1 / 2$ " SS BALL VALVE

$1 / 2$ " SS BALL VALVE

$1 / 8$ " SS BALL VALVE

$1 / 8$ " SS BALL VALVE

$1 / 4$ " SS BALL VALVE

$1 / 4$ " SS BALL VALVE

TEMPERATURE ELEMENT
VENDOR AND PART NO.

WHITEY, SS-12NKRS8

WHITEY, SS-41S2

WHITEY, SS-41S2

WHITEY, SS-41S2

WHITEY, SS-41S2

WHITEY, SS-63TS8

CIRCLE SEALS CONT., 3008S00T-0.15

WHITEY, SS-41S2

NUPRO, SS-SS2

WHITEY, SS-41S2

WHITEY, SS-41S2

WHITEY, SS-41S2

WHITEY, SS-41S2

NUPRO, SS-SS2

WHITEY, SS-41S2

WHITEY, SS-41S2

NUPRO, SS-SS2

WHITEY, SS-41S2

WHITEY, SS-41S2

WHITEY, SS-41S2

WHITEY, SS-41S2

NUPRO, SS-SS2

WHITEY, SS-41S2

WHITEY, SS-63TS8

WHITEY, SS-63TS8

WHITEY, SS-41S2

WHITEY, SS-41S2

WHITEY, SS-62TS4

WHITEY, SS-62TS4

WATLOW/GORDON, RFHLOTK100CA200 
LIST OF COMPONENTS NOT IN THE SAMPLE GAS STREAM:

\begin{tabular}{|c|c|c|}
\hline ACU-*10 & HVAC UNIT & ENCLOSURE \\
\hline DP-*10 & POWER PANEL BOARD $(120 / / 240$ VAC $)$ & ENCLOSURE \\
\hline FIV $* 20$ & LOW FLOW ROTAMETER & WALLACE AND TIERNAN, 32E083S1XX2 \\
\hline FIV-*30 & LOW FLOW ROTAMETER & WALLACE AND TIERNAN, 32E083S1XX2 \\
\hline FLT-*60 & 15 MICRON INLINE FILTER & NUPRO, SS-4FW-15 \\
\hline FLT-*61 & 15 MICRON INLINE FILTER & NUPRO, SS-4FW-15 \\
\hline FLT-*62 & 15 MICRON INLINE FILTER & NUPRO, SS-4FW-15 \\
\hline FLT-*63 & 15 MICRON INLINE FILTER & NUPRO, SS-4FW-15 \\
\hline FLT-*65 & 2 MICRON INLINE FILTER & NUPRO, SS-4FW-2 \\
\hline FLT $-* 69$ & 15 MICRON INLINE FILTER & NUPRO, SS-4FW-15 \\
\hline HT-*10 & SAMPLE GAS LINE HEAT TRACE & O'BRIEN, TPE2-B4-B10 (TPE1-B4-B10) \\
\hline JBX-*10 & JUNCTION BOX ASSEMBLY & ENCLOSURE \\
\hline JY-*10 & SOLID STATE RELAY & POTTER \& BRUMFIELD, SSRT-240D25 \\
\hline JY-*20 & SOLID STATE RELAY & POTTER \& BRUMFIELD, SSRT-240D25 \\
\hline $\mathrm{JY}-* 30$ & SOLID STATE RELAY & POTTER \& BRUMFIELD, SSRT-240D25 \\
\hline MUX-*10 & MULTIPLEXER AMUX-64T & NATIONAL INSTRUMENTS, 776366-90 \\
\hline NT-*40 & FTIR OPTICAL UNIT/PWR SUPPLY & BIORAD, FTS 175/013-4434 \\
\hline PC-*10 & HOST COMPUTER SYSTEM & INTEL 586 (min.) \\
\hline WITH & ANALOG I/O, AT-MIO-16 & NATIONAL INSTRUMENTS, 776578-11 \\
\hline WITH & DIGITAL I/O, PC-DIO-24 & NATIONAL INSTRUMENTS, 776247-01 \\
\hline PC-*20 & NIT-*20 PERSONAL COMPUTER & INTEL $486 / 33$ (min.) \\
\hline PC $-* 30$ & NIT-*30 PERSONAL COMPUTER & INTEL $486 / 33$ (min.) \\
\hline PC- $* 40$ & NIT-*40 PERSONAL COMPUTER & INTEL $486 / 33$ (min.) \\
\hline PCV/PI-*60 & LOW PRESS. REGULATOR/GAGE & MATHESON 3122-580 \\
\hline PCV/PI-*61 & H2 LOW PRESS. REGULATOR/GAGE & MATHESON 3813-350 \\
\hline PCV/PI-*62 & LOW PRESS. REGULATOR/GAGE & MATHESON 3122-580 \\
\hline $\mathrm{PCV} / \mathrm{PI}-* 63$ & CH4 LOW PRESS. REGULATOR/GAGE & MATHESON 3813-350 \\
\hline PCV/PI-*64 & SINGLE STAGE REGULATOR & MATHESON 3421 \\
\hline PCV/PI-*65 & DUAL STAGE REGULATOR & MATHESON 3813 \\
\hline PS-*10 & 24 VOLT DC POWER SUPPLY & ACOPIAN, A24MT210 \\
\hline SOV-*20 & 2 WAY SOLENOID VALVE & HONEYWELL/SKINNER, B2DA1175-110VAC \\
\hline SOV $-* 30$ & 2 WAY SOLENOID VALVE & HONEYWELL/SKINNER, B2DA1175-110VAC \\
\hline SV-*28 & 1/4" SS BALL VALVE & WHITEY, SS-62TS4 \\
\hline SV-*29 & 1/4" SS BALL VALVE & WHITEY, SS-62TS4 \\
\hline SV-*38 & $1 / 4^{\prime \prime}$ SS BALL VALVE & WHITEY, SS-62TS4 \\
\hline SV-*39 & $1 / 4 "$ SS BALL VALVE & WHITEY, SS-62TS4 \\
\hline SV-*48 & 1/4" SS BALL VALVE & WHITEY, SS-62TS4 \\
\hline SV-*49 & 1/4" SS BALL VALVE & WHITEY, SS-62TS4 \\
\hline$S V-* 60$ & 1/4" SS BALL VALVE & WHITEY, SS-62TS4 \\
\hline SV-*61 & 1/4" SS BALL VALVE & WHITEY, SS-62TS4 \\
\hline SV-*62 & $1 / 4 "$ SS BALL VALVE & WHITEY, SS-62TS4 \\
\hline SV-*63 & 1/4" SS BALL VALVE & WHITEY, SS-62TS4 \\
\hline SV-*64 & 1/4" SS BALL VALVE & WHITEY, SS-62TS4 \\
\hline SV-*65 & 1/4" SS BALL VALVE & WHITEY, SS-62TS4 \\
\hline SV-*66 & $1 / 4 "$ SS BALL VALVE & WHITEY, SS-62TS4 \\
\hline SV-*67 & 1/4" SS BALL VALVE & WHITEY, SS-62TS4 \\
\hline SV-*69 & 1/4" SS BALL VALVE & WHITEY, SS-62TS4 \\
\hline
\end{tabular}


LIST OF COMPONENTS NOT IN THE SAMPLE GAS STREAM: (continued)

$\begin{array}{ll}\text { TE-*10 } & \text { TEMPERATURE ELEMENT TYPE K T/C } \\ \text { TE-*11 } & \text { TEMPERATURE ELEMENT } \\ \text { TIC-*10 } & \text { TEMP.INDICATE CONTROL/ALARM } \\ \text { TIT-*11 } & \text { TEMP.INDICATE TRANSMITTER } \\ \text { TIT-*40 } & \text { TEMP.INDICATE TRANSMITTER } \\ \text { TSL-*10 } & \text { HT TEMP ALARM SWITCH- LOW } \\ \text { YY-*10 } & \text { INPUT MODULE SSR-IDC-5 } \\ \text { WITH } & \text { OUTPUT MODULE SSR-ODC-5 } \\ \text { WITH } & \text { SIGNAL CONDITIONING }\end{array}$

TE-*10

TE-*11

TIT-*40

TSL-*10

WITH

WITH
TEMPERATURE ELEMENT TYPE K T/C EMENT

TEMP.INDICATE TRANSMITTER

TEMP.INDICATE TRANSMITTER

HT TEMP ALARM SWITCH- LOW

OUTPUT MODULE SSR-ODC-5

SIGNAL CONDITIONING
GORDON, IAFECOTF720UK300

WATLOW/GORDON, RFHLOTK100CA200

OMEGA, CN9121A

NEWPORT, INFU-0-0-1-0-DC1

NEWPORT, INFU-0-0-1-0-DC1

PART OF TIC-*10

NATIONAL INSTRUMENTS, 776239-01

NATIONAL INSTRUMENTS, 776241-01

NATIONAL INSTRUMENTS, 776290-916 


\section{APPENDIX C - Gas Sample Delivery Speed Calculations}

These calculations were performed to determine the time it takes for a gas sample to travel from the exhaust header to a gas chromatograph sensing element. The original calculation was done for the GMS 2 system and was included in WHC-SD-WM-SDD-003, Waste Tank 241-SY-101 Gas Monitoring System 2 System Design Description, Appendix B. Since the GCS systems will be installed in different tank farms and at different distances from the tank exhaust header, the analysis has been updated and included in this document so the exact time delay for a gas sample delivery can be calculated for each GCS installation. This appendix consists of 7 pages including this page. 


\section{DESIGN CALCULATIONS}
(1) Drawing $\mathrm{H}-14-100438$
(2) Doc. No.
(5) Rev.
(3) Page 1 of 5
(4) Building East Tank Farms
(6) Job No.
(7) Subject Gas Characterization System, Sample Gas Delivery Velocity and Time
(8) Originator I C Schneider Jeghered
(9) Checker BLPhilipe GL Aulyp Date Date $07 / 07 / 98$

Calculate typical sample gas velocities and gas delivery times for the Gas Characterization System (GCS) sample transport system.

\section{Assumptions:}

1. 0.5 inch $00,0.049$ inch wal1 Stainless Steel tubing between the ventilation exhaust header and the GCS enclosure.

2. 0.5 inch 00, 0.049 inch wall Stainless Steel tubing sample delivery to the moisture filter inside the GCS enclosure.

3. 0.125 inch 00, 0.028 inch wall Stainless Steel tubing between the moisture filter and the gas chromatograph (GC) cabinet bulkhead connectors.

4. 0.0625 inch 00, 0.016 inch wal1 Stainless Steel tubing between the cabinet bulkhead connectors and the GC sample volumes.

5. Flow rate between the exhaust header and the GCS is nominal7y $0.5 \mathrm{cfm}$.

6. Flow rate in the GCS sample header is $0.5 \mathrm{cfm}$.

7. Flow rate in the individual GC sample 1 ines is $10 \mathrm{cc} / \mathrm{min}$.

8. The flow is based upon standard temperature and pressure.

9. $1728 \mathrm{in}^{3} / \mathrm{ft}^{3}$

10. $2.5417 \mathrm{~cm} /$ in 


\section{DESIGN CALCULATIONS}
(1) Drawing $\mathrm{H}-14-100438$
(2) Doc. No.
(4) Bui lding East Tank Farms
(5) Rev.
(3) Page 2 of 5
(7) Subject Gas Characterization System Sample Gas Delivery Velocity and Time
(8) Originator TC Schneider Te Date 7-8-98
(9) Checker BLPhilipp BLAnifip Date $\frac{07 / 07 / 98}{}$

\section{Calculations:}

I. Calculate the velocity of gas in the $1 / 2$ inch tube at $0.5 \mathrm{cfm}$.

A. Calculate the volume of gas in one linear foot of 0.5 inch diameter tubing.

$$
\begin{aligned}
& O D=0.50 \text { inch } \\
& \text { Wa } 11=0.049 \text { inch } \\
& I D=0.402 \text { inch }
\end{aligned}
$$

Area :

$$
\pi r^{2}=0.1269 i n^{2}
$$

Volume in one linear foot of tubing:

$$
0.1269 \mathrm{in}^{2} \times 12 \mathrm{in} / \mathrm{ft}=1.523 \mathrm{in}^{3} / \mathrm{ft}
$$

B. Calculate the length of $1 / 2$ inch tubing needed to contain one $\mathrm{ft}^{3}$ of gas.

$$
\frac{1728 i n c h^{3} / f t^{3}}{1.523 i n c h^{3} / f t}=1134.6 f t / f t^{3}
$$

C. Calculate the gas velocity at the flow rate of $0.5 \mathrm{cfm}$.

$$
\begin{gathered}
1134.6 \mathrm{ft} / \mathrm{ft}^{3} \times 0.5 \mathrm{ft}^{3} / \mathrm{min}=567.3 \mathrm{ft} / \mathrm{min} \\
\frac{567.3 \mathrm{ft} / \mathrm{min}}{60 \mathrm{sec} / \mathrm{min}}=9.455 \mathrm{ft} / \mathrm{sec}
\end{gathered}
$$




\section{DESIGN CALCULATIONS}
(1) Drawing $\mathrm{H}-14-100438$
(2) Doc. No
(3) Page 3 of 5
(4) Bui lding East Tank Farms
(5) Rev.
(6) Job No.
(7) Subject Gas Characterization System Sample Gas Delivery Velocity and Time
(8) Originator T C Schneider
(9) Checker
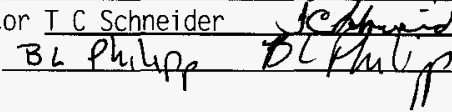

II. Calculate the velocity of gas in the $1 / 8$ inch tube at the flow rate of $10 \mathrm{cc} / \mathrm{min}$.

A. Calculate the volume (cc) of gas in one Tinear inch of 0.125 inch diameter tubing.

$$
\begin{aligned}
& D D=0.125 \text { inch } \\
& \text { Wa11 }=0.028 \text { inch } \\
& I D=0.069 \text { inch }=0.175 \mathrm{~cm}
\end{aligned}
$$

Area :

II $r^{2}=0.024 \mathrm{~cm}^{2}$

Volume in one linear inch of tubing:

$0.024 \mathrm{~cm}^{2} \times 2.5417 \mathrm{~cm} /$ inch $=0.061 \mathrm{~cm}^{3} /$ inch

B. Calculate the length of $1 / 8$ inch tubing required to contain $1 \mathrm{cc}$ of gas.

$$
\frac{1}{0.061 \mathrm{cc} / \mathrm{inch}}=16.39 \mathrm{inch} / \mathrm{cc}
$$

C. Calculate the gas velocity at a flow rate of $10 \mathrm{cc} / \mathrm{min}$.

$$
16.39 \mathrm{inch} / \mathrm{cc} \times 10 \mathrm{cc} / \mathrm{min}=\frac{163.9 \mathrm{inch} / \mathrm{min}}{60 \mathrm{sec} / \mathrm{min}}=2.732 \mathrm{inch} / \mathrm{sec}
$$




\section{DESIGN CALCULATIONS}
(1) Drawing $\mathrm{H}-14-100438$
(2) Doc. No.
(3) Page 4 of 5
(4) Bui lding East Tank Farms
(5) Rev.
(6) Job No.
(7) Subject Gas Characterization System, $\overline{\text { Sample Gas Delivery Velocity and Time }}$
(8) Originator T C Schneider
(9) Checker
sLPhilip BLPhlipp Date 7788 Date $\overline{07 / 07 / 98}$

III. Calculate the velocity of gas in the $1 / 16$ inch tube at the flow rate of 10 $\mathrm{cc} / \mathrm{min}$.

A. Calculate the volume of gas in one linear inch of 0.0625 inch diameter tubing.

$$
\begin{aligned}
& O D=0.0625 \text { inch } \\
& \text { Wa11 }=0.016 \text { inch } \\
& I D=0.0305 \text { inch }=0.0775 \mathrm{~cm}
\end{aligned}
$$

Area :

${ }_{\pi} \mathrm{r}^{2}=0.00472 \mathrm{~cm}^{2}$

Volume in one linear inch:

$0.00472 \mathrm{~cm}^{2} \times 2.5417 \mathrm{~cm} /$ inch $=0.012 \mathrm{cc} /$ inch

B. Calculate the length of $1 / 16$ inch tubing required to contain one cc of gas.

$$
\frac{1}{0.012 \mathrm{cc} / \mathrm{inch}}=83.3 \mathrm{inch} / \mathrm{cC}
$$

c. Calculate the gas velocity at a flow rate of $10 \mathrm{cc} / \mathrm{min}$.

$$
83.3 \mathrm{inch} / \mathrm{cc} \times 10 \mathrm{cc} / \mathrm{min}=\frac{833 \mathrm{inch} / \mathrm{min}}{60 \mathrm{sec} / \mathrm{min}}=13.88 \mathrm{inch} / \mathrm{sec}
$$



(1) Drawing
(2) Doc. No.
(3) Page 5 of $\underline{5}$
(4) Building East Tank Farms
(5) Rev.
(6) Job No.
(7) Subject Gas Characterization System Sample Gas Delivery Velocity and Time
(8) Originator IC Schneider
(9) Checker B< Philips Date Date $0 7 \longdiv { 0 7 / 9 8 }$

IV. Calculate the sample delivery times using the nominal tubing lengths given the sample flow rates of $0.5 \mathrm{cfm}$ and $10 \mathrm{cc} / \mathrm{min}$.

A. Exhaust duct to GCS in 7 et $=75$ feet $(1 / 2$ inch tubing)

B. GCS inlet to $G C$ moisture filter $=8$ feet $(1 / 2$ inch tubing)

C. $G C$ inlet moisture filter to $G C$ cabinet bulkhead $=86$ inches $(1 / 8$ inch tubing)

D. CG cabinet bulkhead to GC sample volume $=10$ feet $(1 / 16$ inch tubing)

A. $\quad 0.5 \mathrm{cfm}$

$$
\frac{75 \mathrm{ft}}{9.455 \mathrm{ft} / \mathrm{sec}}=7.93 \mathrm{sec}
$$

B. $\quad 0.5 \mathrm{cfm}$

$$
\frac{8 \mathrm{ft}}{9.455 \mathrm{ft} / \mathrm{sec}}=0.846 \mathrm{sec}
$$

C. $\quad 10 \mathrm{cc} / \mathrm{sec}$

$$
\frac{86 i n c h}{2.732 i n c h / s e c}=31.48 \mathrm{sec}
$$

D. $10 \mathrm{cc} / \mathrm{sec}$

$$
\frac{120 \mathrm{inch}}{13.88 \mathrm{inch} / \mathrm{sec}}=8.65 \mathrm{sec}
$$

Total sample delivery time $=48.91 \mathrm{sec}(0.815 \mathrm{~min})$ 


\section{CHECKLIST FOR INDEPENDENT REVIEW}

Document Reviewed: Design Calculations for Gas Characterization System Sample Gas Delivery

Velocity and Time

Author

T. C. Schneider

Yes No N/A

[x] [ ] [ ] Problem completely defined?

[x] [ ] [ ] Necessary assumptions explicitly stated and supported?

[ ] [ ] [x] Computer codes and data files documented?

[x] [ ] [ ] Data used in calculations explicitly stated in document?

[x] [ ] [ ] Data checked for consistency with original source information as applicable?

[x] [ ] [ ] Mathematical derivations checked including dimensional consistency of results?

[ ] [ ] [x] Models appropriate and used within range of validity or use outside range of established validity justified?

[x] [ ] [ ] Hand calculations checked for errors?

[ ] [ ] [x] Code run streams correct and consistent with analysis documentation?

[ ] [ ] [x] Code output consistent with input and with results reported in analysis documentation?

[ ] [ ] [x] Acceptability limits on analytical results applicable and supported? Limits checked against sources?

[x] [ ] [ ] Safety margins consistent with good engineering practices?

[x] [ ] [ ] Conclusions consistent with analytical results and applicable limits?

[x] [ ] [ ] Results and conclusions address all points required in the problem stated?

$$
\frac{B L \text { Philipp }}{\text { Reviewer }} \text { BCFilipp } \frac{\text { July 7,1998 }}{\text { Date }}
$$




\section{APPENDIX D - HVAC Analysis for GCS}

This appendix addresses the design analysis of the HVAC system for the GCS (GMS 2) building, refer to WHC-SD-WM-SDD-003, Waste Tank 241-SY-101 Gas Monitoring System 2 System Design Description, Appendix C, HVAC Analysis for GMS 2. Since the same enclosure and environmental requirements are specified for the GCS, the GMS 2 analysis should be applicable to the GCS.

The assumptions and heat load summary for GMS 2 is repeated here, and the heat load for the GCS is given for comparison and to show the heat load reserve for future equipment.

\section{GMS 2 - HVAC Electrical Heat Loads}

\section{GENERAL DESIGN DATA}

* Design Conditions: $\quad$ Summer: $\quad 38^{\circ} \mathrm{C}\left(101^{\circ} \mathrm{FDB}\right), 20^{\circ} \mathrm{C}\left(68^{\circ} \mathrm{FWB}\right)$

Winter: $\quad-13^{\circ} \mathrm{C}\left(9^{\circ} \mathrm{FDB}\right)$

Wind: $\quad 24 \mathrm{~km} / \mathrm{hr}(15 \mathrm{mph})$

* Indoor Design Temperature: $\quad 24 \pm 3^{\circ} \mathrm{C}\left(75 \pm 5^{\circ} \mathrm{FDB}\right)$

\section{ASSUMPTIONS}

* No air infiltration or exfiltration

* Equipment runs continuously and is in operation simultaneously

* UPS and Isolation transformers are $85 \%$ efficient (generate $15 \%$ of their operating load as heat). 


\section{GMS 2 Internal Heat Sources}

I. UPS Load Power

$\begin{array}{llllc}\text { QTY Description } & \mathrm{V} / \mathrm{Hz} / \mathrm{Ph} & & \mathrm{A} / \mathrm{ea} & \mathrm{VA} \\ 1 \text { CPU (GC System) } & 120 / 60 / 1 & & 1.83 & 220 \\ 1 \text { Monitor (GC System) } & 120 / 60 / 1 & 1.5 & 180 \\ 1 \text { Bernoulli disk (GC System) } & 120 / 60 / 1 & 1.0 & 144 \\ 1 \text { LabNet Power Supply (GC System) } & 120 / 60 / 1 & 0.25 & 30 \\ 1 \text { CPU (FTIR System) } & 120 / 60 / 1 & 2.0 & 220 \\ 1 \text { Monitor (FTIR System) } & 120 / 60 / 1 & 1.5 & 180 \\ 1 \text { Modem (FTIR System) } & 120 / 60 / 1 & 0.5 & 60 \\ & & \text { TOTAL } & 1034\end{array}$

II. Isolation Transformer Load Power

\begin{tabular}{llll} 
QTY Description & $\mathrm{V} / \mathrm{Hz} / \mathrm{Ph}$ & $\mathrm{A} / \mathrm{ea}$ & $\mathrm{VA}$ \\
\cline { 2 - 4 } G Gas Chromatographs (10 amps ea) & $120 / 60 / 1$ & 30.0 & 3600 \\
3 GC Integrators (0.4 amps ea) & $120 / 60 / 1$ & 1.2 & 144 \\
1 FTIR Spectrometer/Power Supply & $120 / 60 / 1$ & $8-10$ & $1080 \mathrm{avg}$. \\
1 Current Loop Power Supply & $120 / 60 / 1$ & 2.0 & $\frac{240}{5134}$
\end{tabular}

III. Other Equipment Load Power

QTY Description

1 FTIR Cooling Package

1 Air Dryer (Plug in Rcpt)

IV. Additional Heat Sources

\begin{tabular}{crr}
$\mathrm{V} / \mathrm{Hz} / \mathrm{Ph}$ & $\mathrm{A} / \mathrm{ea}$ & $\mathrm{VA}$ \\
\hline $120 / 60 / 1$ & 7.0 & 840 \\
$120 / 60 / 1$ & 0.8 & 96 \\
& TOTAL & 936
\end{tabular}

TOTAL INTERNAL HEAT GAIN $=1034+5134+936+1160=8264$ VA (watts) $(8264$ Watts $) *(3.414 \mathrm{BTU} / \mathrm{Hr} / \mathrm{Watt})=28,213 \mathrm{BTU} / \mathrm{Hr}$ 


\section{GCS - Internal Heat Sources}

I. Isolation Transformer Load Power

\begin{tabular}{|c|c|c|c|}
\hline QTY Description & $\mathrm{V} / \mathrm{Hz} / \mathrm{Ph}$ & A/ea & $\underline{\mathrm{VA}}$ \\
\hline $\begin{array}{c}3486 \mathrm{DX} 266 \text { CPU's (2.7 amps ea) } \\
\text { (2 ea GC, } 1 \text { ea FTIR) }\end{array}$ & $120 / 60 / 1$ & $3 * 325$ & 975 \\
\hline 1 CPU (GCS Data System) & $120 / 60 / 1$ & 2.7 & 32 \\
\hline 2 Dual Column GC's (0.4 amp ea) & $120 / 60 / 1$ & $2 * 50$ & 100 \\
\hline 1 Computer Monitor (15") & $120 / 60 / 1$ & 1.8 & 216 \\
\hline 1 Computer Monitor $\left(17^{\prime \prime}\right)$ & $120 / 60 / 1$ & 2.6 & 312 \\
\hline 1 Ink Jet Printer & $120 / 60 / 1$ & 1.0 & 120 \\
\hline 1 FTIR Opt.Bch Power Supply & $120 / 60 / 1$ & 4.0 & 480 \\
\hline $124 \mathrm{Vdc}$ Inst. Loop Power Supply & $120 / 60 / 1$ & 1.0 & 120 \\
\hline
\end{tabular}

II. Additional Heat Sources

OTY Description

240 watt Fluorescent Bulbs

1 Isolation Transformer inefficiencies

$\begin{array}{lrr}\frac{\mathrm{V} / \mathrm{Hz} / \mathrm{Ph}}{120 / 60 / 1} \begin{array}{r}\mathrm{A} / \mathrm{ea} \\ 0.34\end{array} & \frac{\mathrm{VA}}{80} \\ 2648 * 0.15=\frac{397}{}= & \\ \text { TOTAL } & 477\end{array}$

TOTAL INTERNAL HEAT GAIN $=2648+477=3125$ VA (watts)

(3125 Watts) $*(3.414 \mathrm{BTU} / \mathrm{Hr} / \mathrm{Watt})=10,669 \mathrm{BTU} / \mathrm{Hr}$

NOTE: The GCS HVAC reserve will be approximately

$8264-3125=5139 \mathrm{VA}$ (Watts)

$28,213-10,669=17.544 \mathrm{BTU} / \mathrm{Hr}$ 


\begin{tabular}{|c|c|c|c|c|c|}
\hline \multicolumn{6}{|c|}{ DISTRIBUTION SHEET } \\
\hline $\begin{array}{l}\text { TO } \\
\text { DISTRIBUTION }\end{array}$ & \multicolumn{3}{|c|}{$\begin{array}{l}\text { From } \\
\text { B.L. Phi 1ipp } \\
\text { COGEMA Engineering Corp. }\end{array}$} & \multicolumn{2}{|c|}{ Date $07 / 16 / 98$} \\
\hline \multirow{2}{*}{\multicolumn{4}{|c|}{$\begin{array}{l}\text { Project Title/work Order } \\
\text { Hydrogen Mitigation Gas Characterization System } \\
\text { System Design Description }\end{array}$}} & \multicolumn{2}{|c|}{ EDT No. 140118} \\
\hline & & & & \multicolumn{2}{|l|}{ ECN No. } \\
\hline Name & MSIN & $\begin{array}{c}\text { Text } \\
\text { with } \\
\text { All } \\
\text { Attach } \\
\text {. }\end{array}$ & $\begin{array}{l}\text { Text } \\
\text { Only }\end{array}$ & $\begin{array}{c}\text { Attach. } \\
\text { Appendi } \\
x \\
\text { Only }\end{array}$ & $\begin{array}{c}\text { EDT/ECN } \\
\text { Only }\end{array}$ \\
\hline $\begin{array}{l}\text { T.C. Schneider } \\
\text { D.D. Tate } \\
\text { B.L. Aftanas } \\
\text { M.F. Erhart } \\
\text { R.L. Schlosser } \\
\text { W.L. Adams } \\
\text { L.S. Krogsrud } \\
\text { B.L. Philipp (3) }\end{array}$ & 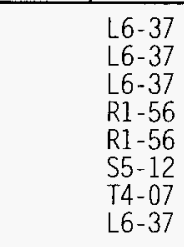 & $\begin{array}{l}x \\
x \\
x \\
x \\
x \\
x \\
x\end{array}$ & & & $x$ \\
\hline Central Files & $B+3+8 \%$ & $x$ & & & \\
\hline W.M. Harty & $S 5-13$ & $x$ & & & \\
\hline
\end{tabular}

